\title{
Thermal characteristics of the testis and epididymis of the boar
}

\author{
B. A. Stone \\ Animal Industry Division, Department of Agriculture, Box 1671, G.P.O., Adelaide, \\ South Australia 5001
}

\begin{abstract}
Summary. Intra-testicular temperatures of conscious boars were in the range $35.0-36.5^{\circ} \mathrm{C}$; values for the caput epididymidis were $35.5-37.0^{\circ} \mathrm{C}$ and for the cauda epididymidis $35 \cdot 3-37 \cdot 0^{\circ} \mathrm{C}$. The modal temperatures of these tissues were $\sim 2.5,1.5$ and $1.9^{\circ} \mathrm{C}$ respectively below rectal temperature $\left(38.2^{\circ} \mathrm{C}\right)$ and each tissue temperature varied diurnally.

With increasing environmental temperature (from 23 to $34^{\circ} \mathrm{C}$ ), testicular and epididymal temperatures increased, and the differential between tissue and rectal temperature levels diminished. The temperature of the caput epididymidis changed most with rising environmental temperature.

It is possible to predict testis or epididymal temperature from environmental or rectal temperature.
\end{abstract}

\section{Introduction}

The testis temperature range over which mammalian spermatogenesis proceeds normally is relatively narrow, and is below body temperature in most species of scrotal mammals studied (Waites, 1970). Within the boar testis, normal temperature levels and their fluctuations have not been well defined and no report on boar epididymal temperature seems to have been published. Setchell (unpublished observations; see Carrick \& Setchell, 1977) found the temperature of the scrotal testis of the boar to be $6^{\circ} \mathrm{C}$ below normal body temperature, but this would appear to be the testis temperature of an anaesthetized animal in view of the differential reported for conscious boars in an earlier study $\left(\sim 2.4^{\circ} \mathrm{C}\right.$; Mazzarri, 1969). The present experiment was carried out to determine mean levels and diurnal variation in epididymal and testicular temperatures of conscious boars.

Between-month variation in fertility of boars has been reported in many areas of the world (Japan: Okauchi \& Hirakata, 1962; France: Corteel, Signoret \& du Mesnil du Buisson, 1964; Thibault et al., 1966; southern Australia: Stone, 1977) and fertility is usually lowest during or immediately after the hottest months (maxima near $36^{\circ} \mathrm{C}$ ). This and other evidence (Mazzarri, du Mesnil du Buisson \& Ortavant, 1968) suggests that testicular functions in the boar are sensitive to heat and this study was therefore extended to examine the thermal responses of the testis and epididymis to environmental heating.

\section{Materials and Methods}

\section{Testicular and epididymal temperatures}

Thermocouples were made by welding a $2-\mathrm{mm}$ twisted junction of $76 \mu \mathrm{m}$ diameter copper and constantan wires by capacitance discharge. The wires were coated with $76 \mu \mathrm{m}$ teflon 
insulation and the junctions were dipped in Araldite (Selleys Chemical Co., Bankstown, New South Wales, Australia). When dry, the resin-cast junctions were sprayed with P.T.F.E. (Chemlon R: John Crane Mauri Pty. Ltd, Moorabbin, Victoria, Australia). The insulated wires were twisted together $5 \mathrm{~cm}$ back from the junction and bent at right angles, at a distance from the junction equivalent to the depth beneath the testicular or epididymal surface at which the couple was to be implanted $(2$ or $1 \mathrm{~cm})$. The twisted portion of the wires was coated with a thin film of Araldite to give rigidity, then resprayed with P.T.F.E. before implantation. Thermocouples were connected to a Rikadenki B-181-H single-pen chart recorder with a cold-junction compensated temperature module (BC 83100, Rikadenki Kogyo Co. Ltd, Tokyo, Japan). Each thermocouple was calibrated against a precision thermometer (Dobros Precision Thermometer, Specification A.S.R. 34, Dobbie Instruments Pty. Ltd, Sandringham, Victoria, Australia) over the temperature range $25-42^{\circ} \mathrm{C}$. Temperatures were recorded to an accuracy of $\pm 0.075^{\circ} \mathrm{C}$ within this range.

Three mature boars $(\mathrm{O}, \mathrm{L}$ and $\mathrm{R})$ were housed in individual pens in a controlled environment room $\left(23^{\circ} \mathrm{C}\right.$ ambient; $12 \mathrm{~h}$ light $/ 12 \mathrm{~h}$ darkness). The animals were fitted with leather girth straps, required for securing and protecting the fine thermocouple leads and adaptor cables. When the animals were accustomed to the girth straps, thermocouple sensors were surgically implanted into the reproductive tissues. The boars were anaesthetized with fluothane (I.C.I.) and nitrous oxide following azaperone (Stresnil, Ethnor Pty Ltd, North Ryde, New South Wales, Australia) premedication. The scrotum was opened to expose the tunica vaginalis. A 19-gauge hypodermic needle was pushed through the tunica vaginalis, avoiding major blood vessels, into the testicular or epididymal tissue, to a depth equivalent to that required for location of the thermocouple junction. The needle was withdrawn and the couple was introduced into the channel cut. The couple was inserted until the rigid bend in the twisted wire portion was at the surface of the testis or epididymis. The rigid twisted wires, on the side of the bend distal to the couple, were laid flat along the organ surface and sutured in 2 places to the tunica vaginalis. A $10-\mathrm{cm}$ loop of wires was then laid on the tunica surface and the scrotum was resutured. The loop allowed the testis to move freely within the scrotum without dislodging the implanted couples. The free ends of the thermocouple wires were fed through subcutaneous fat via a stainless-steel biopsy punch and were connected to copper-constantan adaptor plugs (thermoelectric) which were then fastened firmly to the girth strap and enclosed within a leather pouch. The boars were allowed at least $48 \mathrm{~h}$ for recovery. For remote tissue temperature recording, low resistance copper-constantan adaptor cables were connected between the plugs on the girth strap and the temperature recorder.

The corpus epididymidis lies between and cephalad to the testes. Since the deep dissection necessary to expose this tissue could have affected the blood supply and thermal behaviour of adjacent epididymal and testicular tissues, thermocouples were not implanted in the corpus epididymidis. The testicular and epididymal tissues monitored were accessible by short scrotal incisions.

Tissue temperatures were recorded for $2 \mathrm{~h}$ on each day following surgery and, to show any diurnal tissue temperature fluctuations, tissue and rectal temperatures were recorded hourly, for $25 \mathrm{~h}$, from Boar R 6 days after surgery. Simple linear regressions were calculated for the testicular, epididymal and rectal temperatures recorded during this 25 -h study.

\section{Effect of increased ambient temperature}

To investigate the thermal response of the testis and epididymis to environmental heating, thermocouples were placed in the testis and cauda and caput epididymidis of Boar G (mature). Following recovery and acclimatization to $23^{\circ} \mathrm{C}$ ambient temperature, this animal was subjected to a short-term heat treatment (see Text-fig. 2) in which air temperature reached $38^{\circ} \mathrm{C}$. Simple linear regressions were constructed for tissue, rectal and environmental temperatures recorded 
during this period. Statistical significance of regression coefficients was estimated using the $t$ test (Li, 1969).

Scrotal surface temperatures were measured at 23 and $34^{\circ} \mathrm{C}$ ambient temperature, using a chromel/alumel thermocouple in a surface-temperature sensor (Group Electronics Pty Ltd, Mentone, Victoria, Australia) with an accuracy of $\pm 1.0^{\circ} \mathrm{C}$ ).

Relative humidity in the controlled-temperature room varied between 40 and $56 \%$ during the periods when tissue temperatures were recorded.

Location of the thermocouples was confirmed in all the animals at slaughter. All were in the expected positions.

\section{Results}

Normal testicular and epididymal temperature levels and the effect of heating

Thermocouples gave valid records for up to 25 days after implantation. Loss of function was usually preceded by erratic recording because of loss of continuity in the thermocouple circuit. Only a few breakdowns occurred at the girth strap connections. Most were found at post-mortem to have resulted from breakage of the fine thermocouple wire or leakage of body fluid into the junctions, causing corrosion. Chart records from functioning thermocouples showed the modal intratesticular temperatures of Boars $\mathrm{O}, \mathrm{L}$ and $\mathrm{R}$ to be near $35.7^{\circ} \mathrm{C}$ (range $\left.35.0-36.5^{\circ} \mathrm{C}\right)$ within the testis, $35.8^{\circ} \mathrm{C}\left(35.6-36.5^{\circ} \mathrm{C}\right)$ in the posterior testis, $36.6^{\circ} \mathrm{C}$ $\left(35.5-37.0^{\circ} \mathrm{C}\right)$ in the caput epididymidis and $36.2^{\circ} \mathrm{C}\left(35.3-37.0^{\circ} \mathrm{C}\right)$ in the cauda epididymidis.

Rectal temperature of the 3 boars during the recording periods was $\sim 38 \cdot 1^{\circ} \mathrm{C}(37 \cdot 6-$ $38 \cdot 6^{\circ} \mathrm{C}$ ).

Hourly temperature records from Boar R, 6 days after surgery, are shown in Text-fig. 1 . The mean ( \pm s.e.m.) temperatures of the tissues were: intra-testicular $35.5 \pm 0.2^{\circ} \mathrm{C}$, caput epididymidis $36.8 \pm 0.1^{\circ} \mathrm{C}$, cauda epididymidis $36.5 \pm 0.1^{\circ} \mathrm{C}$ and rectum $38.2 \pm 0.1^{\circ} \mathrm{C}$. Simple least-squares linear regressions between reproductive tissue and rectal temperatures (RT, ${ }^{\circ} \mathrm{C}$ ), recorded hourly during this 25 -h study, gave $-1.02 . \mathrm{RT}+74.54$ for intra-testicular temperature $\left(r^{2}=0.30, P<0.001\right),-1.03 . \mathrm{RT}+75.95$ for the caput epididymidis temperature $\left(r^{2}=0.35, P<0.01\right)$ and $-0.52 . \mathrm{RT}+56.53$ for the cauda epididymidis temperature $\left(r^{2}=\right.$ $0 \cdot 15$, not significant).

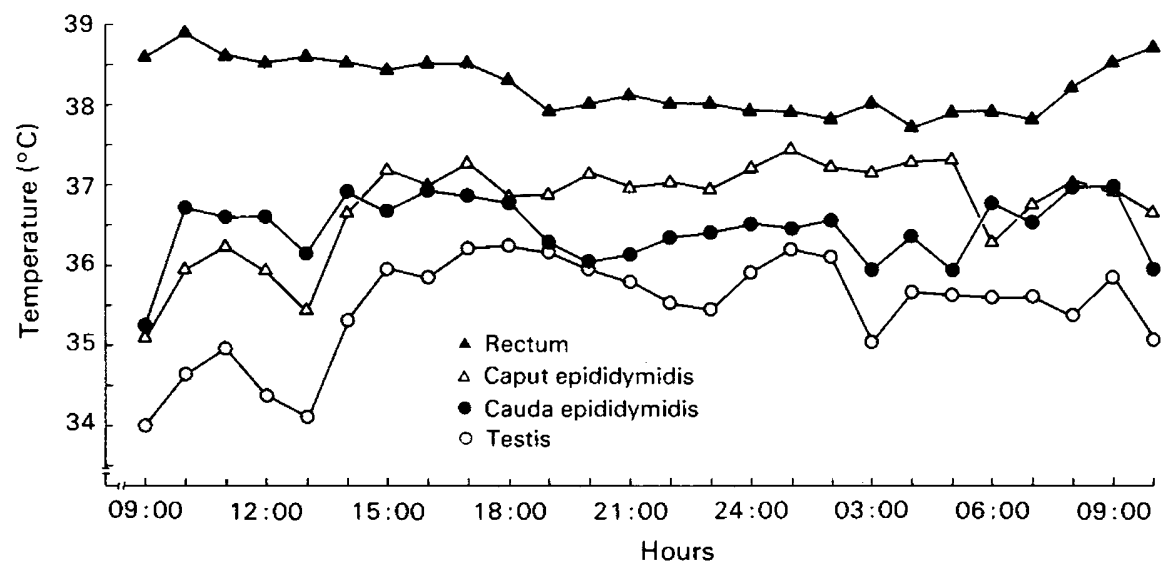

Text-fig. 1. Rectal and tissue temperatures of Boar $\mathrm{R}$ recorded during a 25 -h period at $23^{\circ} \mathrm{C}$ ambient temperature. 
Modal tissue temperatures estimated from the chart records and mean values calculated from hourly measurements agreed closely. Intra-testicular temperatures and those of the caput and cauda epididymidis were $2.5,1.5$ and $1.9^{\circ} \mathrm{C}$ respectively below normal body temperature.

Intra-testicular and epididymal temperatures recorded from Boar $\mathrm{G}$ were within respective normal limits at $22^{\circ} \mathrm{C}$ ambient temperature, but rectal and tissue temperatures increased with heating (Text-fig. 2), the values being correlated $(P<0.001)$ according to the following regressions $\left(\mathrm{RT}=\right.$ rectal temperature): $1.23 . \mathrm{RT}-11.80$ for intra-testicular temperature $\left(r^{2}=\right.$ $0.79), 1.45 . \mathrm{RT}-19.24$ for the caput $\left(r^{2}=0.74\right)$ and 1.08 .RT -5.30 for the cauda epididymidis $\left(r^{2}=0.77\right)$. Similarly, tissue and environmental temperatures $\left(\mathrm{ET},{ }^{\circ} \mathrm{C}\right)$ were significantly $(P<0.001)$ correlated during heating: 0.17 .ET +30.84 for intra-testicular temperature $\left(r^{2}=0.79\right) ; 0.20 . \mathrm{ET}+30.96$ for caput $\left(r^{2}=0.77\right)$ and 0.15 . ET $+32 \cdot 12$ for the cauda epididymidis $\left(r^{2}=0.82\right)$.

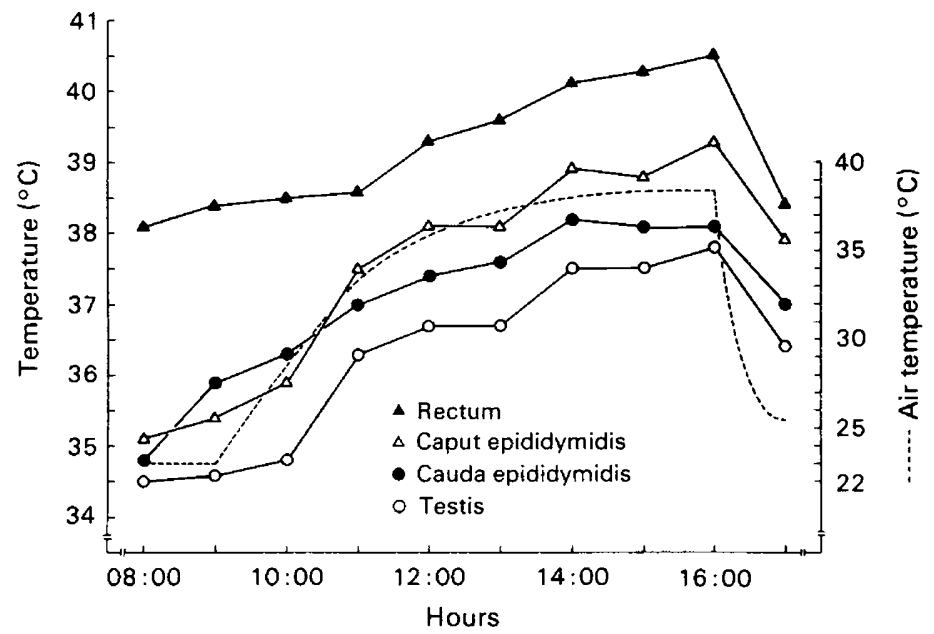

Text-fig. 2. The thermal responses of rectal, testicular and epididymal tissues to changing environmental temperature (--.--).

Measurements of testicular tissue temperatures of Boars R and G, while anaesthetized and on separate occasions, were 32.5 and $32.6^{\circ} \mathrm{C}$ respectively. These values are consistent with the unpublished observations of Setchell (see Carrick \& Setchell, 1977).

\section{Discussion}

The gradients between tissue and body temperatures were similar to those reported for male rats (Brooks, 1973). The temperature of the cauda epididymidis of the boar, however, is between the values for the caput epididymidis and the testis and is not $4^{\circ} \mathrm{C}$ lower as it is in the rat. The similarities in tissue temperature gradients between the male rat and the boar are consistent with similarities between the species in scrotal form and location. Neither boars nor rats sweat effectively, and the lower temperature of the cauda epididymidis of the rat may result from efficient vascular heat exchange local to the cauda, or from more effective dissipation of heat (by convection or conduction) through the prominent ventral apex of the scrotum occupied by the cauda (Bedford, 1977). The cauda epididymidis of the boar underlies a less prominent posterior proximal region of the scrotum (Text-fig. 3).

In comparison with most other male mammals studied (Waites, 1970), the body- 


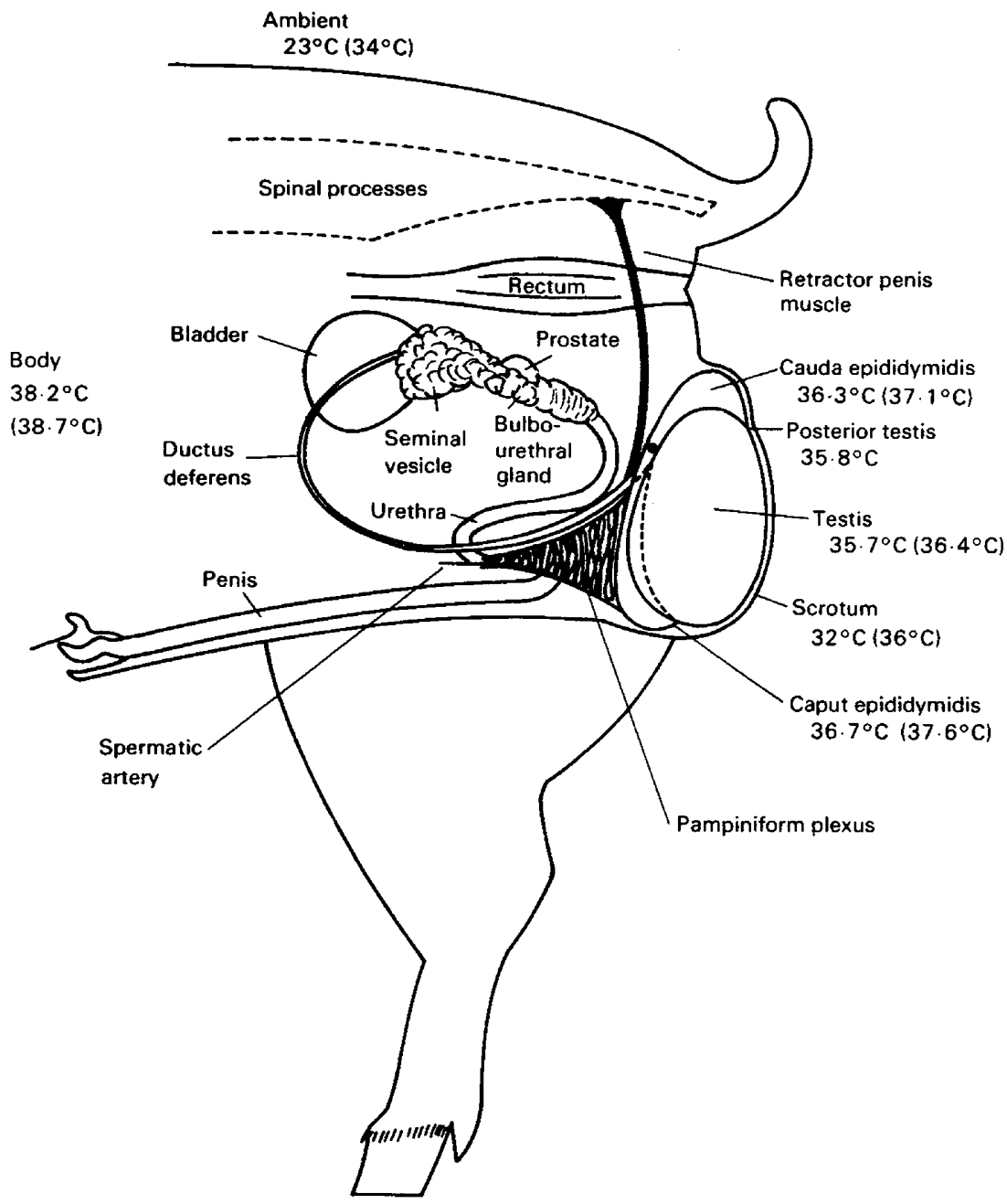

Text-fig. 3. The location of the testis and epididymis of the boar, in relation to the body and scrotum. Normal tissue temperatures at $23^{\circ} \mathrm{C}$ ambient temperature are shown, and the values in parentheses indicate tissue temperatures measured at $34^{\circ} \mathrm{C}$ ambient temperature in the heating study. The higher temperature is near typical daily shade temperature maxima during summer in southern Australia.

testis-epididymis temperature differentials shown in boars in this experiment are small and presumably reflect differences in scrotal form and efficiency of heat dissipation. Body-testis temperature differentials are generally larger in those species with a sweating, pendulous scrotum (e.g. ram, $4 \cdot 5^{\circ} \mathrm{C}$; Waites, 1970 ).

Diurnal changes in testicular and epididymal temperatures (Text-fig. 1) were synchronous, suggesting diurnal variation in a temperature-regulating factor common to each organ, such as blood supply to the scrotum or pampiniform plexus. Diurnal temperature variations in these tissues were greater than, and inversely related to, body temperature variations. This suggests that, within the normal physiological range of body temperature $\left(37.6-38.6^{\circ} \mathrm{C}\right)$ and at constant ambient temperature $\left(23^{\circ} \mathrm{C}\right)$, testicular and epididymal temperatures are determined by factors additional to the temperature of blood flowing into the pampiniform plexus. Since the rate of heat dissipation from the scrotum should be constant at stable ambient temperature, variation in testicular and epididymal blood-flow appears the most likely factor. 
The small difference in temperature between the centre and the posterior margin of the testis shows that, if a temperature gradient across the testis exists, it is very slight.

The amount of change in tissue temperatures during heating (Text-fig. 2) shows that the caput epididymidis is the most thermally responsive tissue. The statistical significance of the regression coefficients indicates that, under the environmental conditions used in this study, rectal temperature or environmental temperature could be used, together or separately, to estimate tissue temperatures indirectly. Since the regressions have been derived from data on animals housed under conditions of controlled temperature and stable humidity, they may be less precise when humidity, radiation and air movement are widely different.

The diminishing differential between tissue and rectal temperatures, with increasing environmental temperatures, shows either that there is a change in rate of heat exchange in the pampiniform plexus during heating, or that there is lower efficiency of heat dissipation from the testis and epididymis than from the body. Blood temperature measurement and studies of blood flow in the pampiniform plexus would elucidate the mechanisms involved.

Scrotal and testis temperatures at an environmental temperature of $34^{\circ} \mathrm{C}$ (Text-fig. 3) reflect the ineffectiveness of sweating in surface cooling of the pig (Threlkeld, 1962; Ingram, 1965; Mount, 1968; Ingram \& Mount, 1975) and show that the scrotal and testicular tissue temperatures of the boar are closely related during heating, as suggested previously for the ram (Moule \& Knapp, 1950; Waites \& Moule, 1961). Physiological bases for this inter-relationship in other scrotal mammals have recently been reviewed (Setchell, 1978). The areas of scrotum in contact with the caput and cauda epididymidis are small in comparison with the area covering the testis (taking account of the apparent differences in masses of these tissues) and epididymal temperatures exceeded testicular temperature at 23 and $34^{\circ} \mathrm{C}$ ambient (Text-fig. 3). Heat dissipation through the scrotum therefore appears to be important in the maintenance of normal tissue temperatures in the boar. However, metabolic heat production in testicular and epididymal tissues and the temperature of inflowing arterial blood will also influence tissue temperatures. Neither of these factors has been studied in detail in the pig, although study of a single boar (Stone, 1980) has shown that the proportion of dorsal aortal blood perfusing the caput epididymidis (per unit mass of tissue) exceeds that of the cauda which, in turn, is greater than that of the testis. Setchell, Waites \& Till (1964) suggested that a region of high blood flow is also a region of high metabolic activity, so Stone's (1980) results are consistent with the differences between epididymal and testicular temperatures measured in this experiment.

Bedford's (1977) 'prime mover' hypothesis implies that the disposition of the epididymis in scrotal species would ensure that the temperature of the cauda epididymidis is lower than that of the testis. The epididymides of the boar are arranged between and cephalad to the testes and are not laid close to the body surface, so differences between testicular and epididymal temperatures should be expected. The results of this study are relevant to Bedford's theory, although they do not support it.

I thank Dr C. F. Cargill (Institute of Medical and Veterinary Science, Adelaide) for assistance in the surgical procedures, and Professor W. V. Macfarlane (University of Adelaide) for valuable discussion during the course of this work and useful criticisms of the draft manuscript. The work was supported by a grant from the Australian Pig Industry Research Committee.

\section{References}

Bedford, J.M. (1977) Evolution of the scrotum: the epididymis as the prime mover? In Reproduction and Evolution, pp. 171-182. Eds J. H. Calaby \& C. H. Tyndaie-Biscoe. Australian Academy of Science, Canberra.
Brooks, D.E. (1973) Epididymal and testicular temperature in the unrestrained conscious rat. J. Reprod. Fert. 35, 157-160.

Carrick, F.N. \& Setchell, B.P. (1977) The evolution of the scrotum. In Reproduction and Evolution, pp. 
165-170. Eds J. H. Calaby \& C. H. Tyndale-Biscoe. Australian Academy of Science, Canberra.

Corteel, J.M., Signoret, J.P. \& du Mesnil du Buisson, F. (1964) Variations saissonnieres de la reproduction de la truie et facteurs favorisant l'anoestrus temporale. Proc. 5th Int. Congr. Anim. Reprod. \& A.I., Trento $3,536$.

Ingram, D.L. (1965) The effect of humidity on temperature regulation and cutaneous water loss in the young pig. Res. Vet. Sci. 6, 9-17.

Ingram, D.L. \& Mount, L.E. (1975) Man and Animals in Hot Environments, p. 61. Springer-Verlag, Berlin.

Li, J.C.R. (1969) Statistical Inference, Vol. 1, p. 302. Edwards Brothers Inc., Ann Arbor.

Mazzarri, G. (1969) Action de la temperature et de la lumière sur la spermatogenèse, sur la production de spermatozoides et le pouvoir fécondant du sperme chez le verrat. Thèse doctoral d'Université, Paris.

Mazzarri, G., du Mesnil du Buisson, F. \& Ortavant, R. (1968) Action of temperature on spermatogenesis, sperm production and fertility of the boar. Proc. 6 th Int. Congr. Anim. Reprod. \& A.I., Paris 1, 305-308.

Moule, G.R. \& Knapp, B. (1950) Observations on intra-testicular temperatures of Merino rams. A ust. J. agric. Res. 1, 456-464.

Mount, L.E. (1968) The Climatic Physiology of the Pig, pp. 14-35. Edward Arnold, London.

Okauchi, K. \& Hirakata, K. (1962) Studies on the characters of boar semen. I. Effects of environmental temperature. Bull. Fac. Agric. Univ. Miyazaki 7, 117. [Anim. Breed. Abstr. 31, 388.]
Setchell, B.P. (1978) The scrotum and thermoregulation. In The Mammalian Testis, pp. 90-108. Ed. B. P. Setchell. Paul Elek, London.

Setchell, B.P., Waites, G.M.H. \& Till, A.R. (1964) Variations in flow of blood within the epididymis and testis of the sheep and rat. Nature, Lond. 203, 317-318.

Stone, B.A. (1977) Between and within herd variation in conception rates in pig herds in the Lower North of South Australia. Agric. Rec., Sth Aust. 4, 22-25.

Stone, B.A. (1980) Studies on the effects of elevated environmental temperature on fertility of the boar. M.Ag.Sc. thesis, University of Adelaide.

Thibault, C., Courot, M., Martinet, L., Mauléon, P., du Mesnil du Buisson, F., Ortavant, R., Pelletier, J. \& Signoret, J.P. (1966) Regulation of breeding season and oestrous cycles by light and external stimuli in some mammals. In Environmental Influences on Reproductive Processes, pp. 119-142. Eds W. Hansel \& R. H. Dutt. Supplement to J. Anim. Sci. 25.

Threlkeld, J.R. (1962) Thermal Environment Engineering, pp. 400-401. Prentice Hall, Inc., Englewood Cliffs.

Waites, G.M.H. (1970) Temperature regulation and the testis. In The Testis, vol. 1, pp. 241-279. Eds A. D. Johnson, W. R. Gomes \& N. L. VanDemark, Academic Press, New York.

Waites, G.M.H. \& Moule, G.R. (1961) Relation of vascular heat exchange to temperature regulation in the testis of the ram. J. Reprod. Fert. 2, 213-224.

Received 19 February 1981 